\title{
Anacardium microcarpum Promotes Neuroprotection Dependently of AKT and ERK Phosphorylation but Does Not Prevent Mitochondrial Damage by 6-OHDA
}

\author{
Illana Kemmerich Martins, ${ }^{1}$ Nélson Rodrigues de Carvalho, ${ }^{1,2}$ \\ Giulianna Echeverria Macedo, ${ }^{1}$ Nathane Rosa Rodrigues, ${ }^{1,3}$ Cynthia Camila Ziech, \\ Lúcia Vinadé, ${ }^{1}$ Valter Menezes Barbosa Filho, ${ }^{4}$ Irwin Alencar Menezes $\mathbb{D}^{4},{ }^{4}$ Jeferson Franco, ${ }^{1}$ \\ and Thaís Posser ${ }^{1}{ }^{1}$ \\ ${ }^{1}$ Oxidative Stress and Cell Signaling Research Group, Centro Interdisciplinar de Pesquisa em Biotecnologia, Universidade Federal \\ do Pampa, Campus São Gabriel, 97300-000 São Gabriel, RS, Brazil \\ ${ }^{2}$ Instituto Federal Farroupilha, Campus Santo Ângelo, 98806-700 Santo Ângelo, RS, Brazil \\ ${ }^{3}$ Departamento de Química, Programa de Pós-Graduação em Bioquímica Toxicológica, Universidade Federal de Santa Maria, \\ 97105-900 Santa Maria, RS, Brazil \\ ${ }^{4}$ Departamento de Química Biológica, Universidade Regional do Cariri, 63100-000 Crato, CE, Brazil
}

Correspondence should be addressed to Thaís Posser; thaisposser@unipampa.edu.br

Received 12 June 2018; Revised 11 August 2018; Accepted 18 August 2018; Published 29 October 2018

Academic Editor: Francisco Jaime Bezerra Mendonça Júnior

Copyright (c) 2018 Illana Kemmerich Martins et al. This is an open access article distributed under the Creative Commons Attribution License, which permits unrestricted use, distribution, and reproduction in any medium, provided the original work is properly cited.

Parkinson's disease is a degenerative and progressive illness characterized by the degeneration of dopaminergic neurons. 6-hydroxydopamine (6-OHDA) is a widespread model for induction of molecular and behavioral alterations similar to Parkinson and has contributed for testing of compounds with neuroprotective potential. The Brazilian plant Anacardium microcarpum is used in folk medicine for treatment of several illnesses; however, the knowledge about toxicology and biological effects for this plant is very rare. The neuroprotective effect from hydroalcoholic extract and methanolic and acetate fraction of A. microcarpum on 6-OHDA-induced damage on chicken brain slices was investigated in this study. 6-OHDA decreased cellular viability measured by MTT reduction assay, induced lipid peroxidation by HPLC, stimulated Glutathione-S-Transferase and Thioredoxin Reductase activity, and decreased Glutathione Peroxidase activity and the total content of thiols containing compounds. The methanolic fraction of A. microcarpum presented the better neuroprotective effects in 6-OHDA-induced damage in relation with hydroalcoholic and acetate fraction. The presence of AKT and ERK1/2 pharmacological inhibitors blocked the protective effect of methanolic fraction suggesting the involvement of survival pathways in the neuroprotection by the plant. The plant did not prevent 6-OHDA autoxidation or 6-OHDA-induced mitochondrial dysfunction. Thus, the neuroprotective effect of the methanolic fraction of A. microcarpum appears to be attributed in part to chelating properties of extract toward reactive species and is dependent on ERK1/2 and AKT phosphorylation. This study contributes to the understanding of biochemical mechanisms implied in neuroprotective effects of the vegetal species A. microcarpum.

\section{Introduction}

The Brazilian plant Anacardium microcarpum, popularly known as "cajui," belongs to the Anacardiaceae family. It is found in the Northeast Region of Brazil and is used in traditional folk medicine for treatment of infectious diseases, inflammation, rheumatism, and tumor. Phytochemical constitution of A. microcarpum stem bark crude extract and fractions demonstrating the presence of different flavonoids such as gallic acid, caffeic acid, and quercetin [1]. 
Although a limited number of studies on this plant is available, our group demonstrated in vitro antioxidant potential and antibacterial effect of this plant [2].

Parkinson's disease (PD), which was described by James Parkinson in 1817, is the second most frequent neurodegenerative disease after Alzheimer's disease and is characterized by a progressive nigrostriatal neurodegeneration. This illness reaches all ethnic groups and socioeconomic classes and is present in approximately $1 \%$ of the world population over the 60s [3]. PD symptoms include resting tremor, stiffness, bradykinesia, and gait impairment [4]. The symptoms onset indicates an advanced stage of disease, with a substantial loss of dopaminergic cells in the substantia nigra and an $80 \%$ depletion of striatum dopamine [5]. It is known that genetic, environmental, and aging factors contribute to the progression of disease [6]. Moreover, biochemical factors such as oxidative stress, mitochondrial dysfunction, inflammation, and apoptotic cell death play important roles in the pathogenesis of PD $[7,8]$.

Substances able to damage selectively dopaminergic neurons are useful tools to study molecular mechanisms implied in neurodegeneration in PD and for screening of neuroprotective potential of chemicals. Among those substances are MPTP, paraquat, rotenone, and 6-hydroxydopamine [9].

6-hydroxydopamine (6-OHDA) is a toxic dopamine metabolite which is rapidly and nonenzymatically oxidized by molecular oxygen to form $p$-quinone and hydrogen peroxide [10] and is proposed as a putative neurotoxic factor contributing for PD pathogenesis. The induction of reactive oxygen species (ROS) formation is a major mechanism implied in neurotoxicity of 6-OHDA. Some characteristics of the brain tissue make it very susceptible to oxidative stress such as the elevated consumption of oxygen, high content of unsaturated fatty acids, and iron levels [11].

The most effective drug in the treatment of $\mathrm{PD}$ is L-DOPA; however, its frequent use is associated with neurotoxicity once L-DOPA gives rise to 6-OHDA via nonenzymatic reactions [12]. It is important to consider that the therapies available for PD delay the progression of degeneration and symptoms instead of providing an effective treatment for the disease. Thus, the search for alternative therapies such as natural antioxidants has grown greatly over the years; besides, there are evidence that plant extracts have beneficial potential, attenuating the progression of $\mathrm{PD}$, through antioxidant compounds present in extracts [13-15]. The model of brain slices has provided an important contribution for detailing of brain circuits and neurochemical mechanisms and testing of the neuroprotective potential of compounds. The main factor why this model is considered appropriate for studying biochemical events in the brain is the maintenance of extracellular matrix, neuronal connectivity, and neuronal-glial interactions [16].

This study is aimed at evaluating the neuroprotective potential and the mechanisms that mediate the neuroprotection of A. microcarpum hydroalcoholic extract (AMHE), methanolic (AMMF), and ethyl acetate (AMEAF) fractions against 6-hydroxydopamine- (6-OHDA-) induced damage on cortical slices.

\section{Materials and Methods}

2.1. Chemicals. Dimetil sulfoxide (DMSO), Folin-Ciocalteu, 2,2'-azino-bis(3-ethylbenzothiazoline-6-sulfonic acid diammonium salt, sodium acetate, HEPES minimum 99.5\% titration, albumin from bovine serum (BSA), reduced glutathione (GSH), oxidized glutathione, tetramethylethylenediamine (TEMED), 3-(4,5-dimethylthiazol-2-yl)-2,5-diphenyltetrazolium bromide (MTT), D-Manitol, $\mathrm{K}_{2} \mathrm{HPO}_{4}, \mathrm{KH}_{2} \mathrm{PO}_{4}$, Triton X-100, $\beta$-mercaptoethanol, anti-rabbit immunoglobulin (HRP peroxidaselinked antibody), and carbonyl cyanide 4-(trifluoromethoxy) phenylhydrate (FCCP) were obtained from Sigma-Aldrich (São Paulo, SP, Brazil). SDS, acrylamide, bis-acrylamide, and hybond nitrocellulose were obtained from GE Healthcare Life Division (Uppsala, Sweden). Anti-phospho-p38 (Thr180/Tyr182) and total form, anti phospho-AKT (Thr308) and total form, anti-phospho PTEN, antiphospho and total JNK1/2 (Thr183/Tyr185), anti-phospho ERK1/2 (Thr202/Tyr204) and anti-total-ERK1/2, and $\beta$-actin antibodies were purchased from Cell Signaling Technology (Danvers, MA). Poly (ADP)-ribose polymerase (PARP) antibody was obtained from Santa Cruz Biotechnology (Santa Cruz, CA). Kit Caspase-Glo 3/7 was obtained from Promega (Madison, WI). All other reagents were commercial products of the highest purity grade available.

2.2. Animals. For this study, it used chicks of Gallus gallus species from both genders with age among 5-15 days. The animals were maintained in the animal facility at controlled conditions of light and temperature with food and water ad libitum. All procedures were performed in accordance with the approval, under protocol no. 011/2012, of the CEUA/ UNIPAMPA (Animal Ethics Committee from Universidade Federal do Pampa).

2.3. Plant Collection and Extractions. The stem barks of A. microcarpum were collected from Barreiro Grande, Crato-Ceará ( $7^{\circ} 22 \_S ; 39^{\circ} 28 \_W ; 892 \mathrm{~m}$ sea level), Brazil, in November 2011. The plant material was identified by Dr. Maria Arlene Pessoa da Silva of the herbarium Caririense Dárdano de Andrade-Lima (HCDAL) of the Regional University of Cariri (URCA), and a voucher specimen was deposited ( $n^{\circ}$ 6702). The fresh barks of $A$. microcarpum were macerated with $99.9 \%$ of ethanol and water $(1: 1, \mathrm{v} / \mathrm{v})$ for 3 days. The suspension was filtered, and the solvent evaporated and lyophilized under reduced pressure to obtain $490 \mathrm{~g}$ of hydroalcoholic extract. One hundred and fifty grams $(150 \mathrm{~g})$ of this was partitioned with ethyl acetate and methanol to obtain $12.5 \mathrm{~g}$ of ethyl acetate fraction and $105.23 \mathrm{~g}$ of the methanolic fraction. All fractions were stored in the freezer and resuspended in water prior to experiments.

2.4. Identification and Quantification of Phenolic Compounds and Flavonoids of Anacardium microcarpum by HPLC-DAD. The chemical composition of the A. microcarpum hydroalcoholic extract (AMHE), A. microcarpum methanolic fraction (AMMF), and A. microcarpum ethyl acetate fraction (AMEAF) was previously determined by our group [1] as shown in Table 1 . The complete study can be found in literature where differences were verified between 
TABLE 1: Phytochemical characterization of extract and fractions of Anacardium microcarpum. (Adapted from Barbosa-Filho et al., 2014.)

\begin{tabular}{lccc}
\hline Compounds & $\begin{array}{c}\text { AMHE } \\
(\mathrm{mg} / \mathrm{g})\end{array}$ & $\begin{array}{c}\text { AMMF } \\
(\mathrm{mg} / \mathrm{g})\end{array}$ & $\begin{array}{c}\text { AMEAF } \\
(\mathrm{mg} / \mathrm{g})\end{array}$ \\
\hline Gallic acid & $14.53 \pm 0.02$ & $7.13 \pm 0.01$ & $21.32 \pm 0.04$ \\
Chlorogenic acid & $5.83 \pm 0.03$ & - & $10.57 \pm 0.03$ \\
Caffeic acid & $19.36 \pm 0.02$ & $13.57 \pm 0.05$ & $27.19 \pm 0.03$ \\
Ellagic acid & $15.12 \pm 0.01$ & $13.19 \pm 0.01$ & $25.61 \pm 0.05$ \\
Catechin & $3.79 \pm 0.01$ & $3.05 \pm 0.04$ & $6.24 \pm 0.02$ \\
Epicatechin & $4.53 \pm 0.01$ & $3.11 \pm 0.01$ & $9.35 \pm 0.01$ \\
Rutin & $3.81 \pm 0.03$ & $9.86 \pm 0.03$ & $7.03 \pm 0.01$ \\
Isoquercitrin & $14.25 \pm 0.01$ & $15.79 \pm 0.03$ & $25.98 \pm 0.02$ \\
Quercetrin & $7.29 \pm 0.02$ & $13.20 \pm 0.02$ & $20.64 \pm 0.02$ \\
Quercetin & $28.03 \pm 0.04$ & $18.16 \pm 0.01$ & $27.02 \pm 0.01$ \\
Kaempferol & $3.54 \pm 0.01$ & $9.93 \pm 0.02$ & $11.25 \pm 0.02$ \\
Kaempferol glycoside & $9.06 \pm 0.03$ & $3.15 \pm 0.04$ & $3.47 \pm 0.01$ \\
\hline
\end{tabular}

hydroalcoholic extract, methanolic, and ethyl acetate fractions, respectively.

2.5. Tissue Slice Preparation and Treatment. Animals were euthanized by decapitation under anesthesia. The brain was dissected and placed in cutting solution oxygenated at $4^{\circ} \mathrm{C}$ (110 mM sucrose, $60 \mathrm{mM} \mathrm{NaCl}, 3 \mathrm{mM} \mathrm{KCl,} 0.5 \mathrm{mM} \mathrm{CaCl}$, $7 \mathrm{mM} \mathrm{MgSO}_{4}, 5 \mathrm{mM}$ glucose, and $25 \mathrm{mM}$ HEPES $\mathrm{pH} 7.4$ ). The cortical region was separated, and $400 \mu \mathrm{m}$ thickness slices were prepared in a McIlwain tissue slicer [17]. The diameter of slices was standardized using a $3 \mathrm{~mm}$ punch. Briefly, slices were transferred to 96 -well plates containing HEPES-saline buffer $(124 \mathrm{mM} \mathrm{NaCl}, 4 \mathrm{mM} \mathrm{KCl}, 1.2 \mathrm{mM}$ $\mathrm{MgSO}_{4}, 12 \mathrm{mM}$ glucose, $1 \mathrm{mM} \mathrm{CaCl}$, and $25 \mathrm{mM}$ HEPES pH 7.4) previously oxygenated during 30 minutes $(200 \mu \mathrm{L} /$ slice). After $30 \mathrm{~min}$ of preincubation, the buffer was removed, and fresh buffer was added. Tissue slices were subsequently incubated for 120 minutes at $37^{\circ} \mathrm{C}$ in the presence/absence of 6-OHDA $500 \mu \mathrm{M}$ and/or hydroalcoholic extract (AMHE), methanolic (AMME), and ethyl acetate A. microcarpum fractions (AMEA) (concentrations among $0.1-1 \mathrm{mg} / \mathrm{mL}$ ). All dissolved in the culture medium.

2.6. Cell Viability. Cell viability was determined by the reduction of 3-(4,5-dimethylthiazol-2-yl)-2,5-diphenyltetrazolium bromide (MTT) (0.05\% HEPES-saline). After 120 minutes of treatment, slices were incubated for 30 minutes at $37^{\circ} \mathrm{C}$ in the presence of MTT [17]. Subsequently, MTT was removed, and samples were incubated in DMSO for $30 \mathrm{~min}\left(37^{\circ} \mathrm{C}\right)$. The absorbance resulted from formazan product diluted in DMSO was read at $540 \mathrm{~nm}$ in an EnsPire ${ }^{\circledR}$ multimode plate reader (PerkinElmer, USA).

2.7. Spectrophotometric Studies of 6-OHDA Autoxidation. The autoxidation of 6-OHDA was followed by monitoring the formation of $p$-quinone at $490 \mathrm{~nm} \mathrm{[10].} \mathrm{A} \mathrm{Cary} \mathrm{60-UV-}$ Visible Spectrophotometer by Agilent Technologies was used for the assay. The cuvette holder was thermostatically maintained at $37^{\circ} \mathrm{C}$. For each assay, $1 \mathrm{~mL}$ of phosphate buffer ( $\mathrm{pH}$ 7.4) was incubated in a quartz cuvette for $10 \mathrm{~min}$ to reach the set temperature. Then, the autoxidation was initiated with the addition of $5 \mu \mathrm{L}$ of a stock solution of 6-OHDA (100 mM) at a final concentration of $0.5 \mathrm{mM}$. The monitoring of the corresponding kinetics was immediately initiated and maintained for subsequent $3 \mathrm{~min}$. To verify if AMHE, AMMF, and AMEAF could prevent autoxidation of the compound, different concentrations of the plant extract or fractions $(1 \mu \mathrm{g} / \mathrm{mL}, 10 \mu \mathrm{g} / \mathrm{mL}$, and $100 \mu \mathrm{g} / \mathrm{mL})$ were added in the presence or absence of 6-OHDA. GSH $10 \mathrm{mM}$ was used as positive control.

2.8. Lipid Peroxidation. The final product from lipid peroxidation was determined with thiobarbituric acid as the reactive substance (TBARS) with some modifications [18]. Tissue slices were incubated for 120 minutes at $37^{\circ} \mathrm{C}$ in different extract concentrations $(0.1-1 \mathrm{mg} / \mathrm{mL})$ in the presence/ absence of 6-OHDA $(500 \mu \mathrm{M})$. For the next step, five slices per treatment group were homogenized in $150 \mu \mathrm{L}$ of HEPES $20 \mathrm{mM}$ buffer. Further, all content was incubated during 60 minutes at $95^{\circ} \mathrm{C}$ into acetic acid/ $\mathrm{HCl} 0.45 \mathrm{M}$ buffer, thiobarbituric acid $0.8 \%$ (TBA), SDS $8.1 \%$ to promote the coloring, and absorbance was measured at $532 \mathrm{~nm}$.

2.9. Enzyme Assays. Glutathione S-transferase activity (GST) was assayed using 1-chloro 2,4-dinitrobenzene (CDNB) as substrate [19]. The assay is based on the formation of the conjugated complex of CDNB and GSH. The reaction was conducted in a mix consisting of $0.1 \mathrm{M}$ phosphate buffer $\mathrm{pH} 7.0,1 \mathrm{mM}$ EDTA, $1 \mathrm{mM} \mathrm{GSH}$, and $2.5 \mathrm{mM}$ CDNB. Glutathione peroxidase activity (GPx) was measured and defined as the rate of NADPH oxidation by the coupled reaction with glutathione reductase [20]. One unit of GPx will consume $1.0 \mu \mathrm{mol}$ of $\mathrm{NADP}^{+}$from NADPH per minute $\left(\varepsilon=6.22 \mathrm{M}^{-1} \mathrm{~cm}^{-1}\right)$. Thioredoxin reductase (Trx-R) activity consists in measuring the rate of reduction of DTNB by NADPH [21]. One unit of enzyme activity was considered the amount of enzyme that catalyzes the formation of $1.0 \mu \mathrm{mol}$ of DTNB per minute at $25^{\circ} \mathrm{C}, \mathrm{pH} 7.0$ $\left(\varepsilon=13.60 \mathrm{M}^{-1} \mathrm{~cm}^{-1}\right)$. All spectrophotometric assays were performed at $340 \mathrm{~nm}$ in an Agilent Cary 60 UV/VIS spectrophotometer with an 18 cell holder accessory coupled to a Peltier Water System temperature controller (Santa Clara, CA).

2.10. Determination of Reduced (GSH) and Oxidized Glutathione (GSSG). For the measurement of GSH and GSSG levels, brain homogenate was treated with $0.5 \mathrm{~mL}$ of $13 \%$ trichloroacetic acid and centrifuged at $100.000 \mathrm{~g}$ for $30 \mathrm{~min}$ at $4^{\circ} \mathrm{C}$. Aliquots $(10 \mu \mathrm{L})$ of supernatant were mixed with $100 \mathrm{mM} \mathrm{NaH}_{2} \mathrm{PO}_{4}$ buffer, pH 8.0, containing $5 \mathrm{mM}$ EDTA. $O$-phthalaldehyde (OPT) $(1 \mathrm{mg} / \mathrm{mL})$ was added, and fluorescence was measured 15 min later using the $350 / 420 \mathrm{~nm}$ excitation/emission wavelength pair in Perkin Elmer inspire [22]. For measurement of GSSG levels, brain supernatant was incubated at room temperature with $\mathrm{N}$-ethylmaleimide (NEM) $(0.04 \mathrm{M})$ for $30 \mathrm{~min}$ at room temperature, and after that, were added $\mathrm{NaOH}(0.1 \mathrm{~N})$ buffer, following of added 
OPT and incubated for $15 \mathrm{~min}$ in the dark, using the procedure outlined above for GSH assay. Results were presented as the GSH/GSSG ratio.

2.11. High-Resolution Respirometry (HRR) In Vitro. For respirometry determination, chick brain (400 mg) was weighed and transferred to $1 \mathrm{~mL}$ of cold homogenization buffer containing $5 \mathrm{mM}$ Tris- $\mathrm{HCl}, 250 \mathrm{mM}$ sucrose, and 2 mM EGTA ( $\mathrm{pH} 7.4$ ), and brain homogenate was used to the HRR. Oxygraph-2k (O2k, OROBOROS Instruments, Innsbruck, Austria) was employed for all respiration measurements. Experiments were performed in $2 \mathrm{~mL}$ of MiR05 buffer (110 mM sucrose, $60 \mathrm{mMK}$-lactobionate, $0.5 \mathrm{mM}$ EGTA, $3 \mathrm{mM} \mathrm{MgCl}_{2}, 20 \mathrm{mM}$ taurine, $10 \mathrm{mM} \mathrm{KH_{2 }} \mathrm{PO}_{4}$, $20 \mathrm{mM}$ HEPES pH 7.4, and 0.1\% BSA) [23]. All experiments were performed at $37^{\circ} \mathrm{C}$ using DatLab 4.0 software (Oroboros Inc., Austria), with continuous stirring at 750 RPM, and all experiments started by registering the endogenous substrate supported respiration, following protocols established in the literature [24].

All experiments of mitochondrial bioenergetics analysis in brain homogenate were performed following [25] with minor modifications at the $\mathrm{O} 2 \mathrm{k}$-chamber. All concentrations of compounds (control group without treatment, $100 \mu \mathrm{g} / \mathrm{mL}$ of a methanolic fraction, 6-OHDA $500 \mu \mathrm{M}$ in the absence or presence of methanolic fraction) were added at the O2k-chamber after signal stabilization of the basal respiration supported by endogenous substrates. Four individual preparations of the brain homogenate were performed per group.

2.12. Mitochondrial Respiration Assays. Titration protocols of multiple substrates and inhibitors were used to assess mitochondrial function in terms of different respiration states. The routine of electron transport system activities in brain homogenate was carried out according to literature [26]. Malate, glutamate, and succinate were used as oxidizable substrates in all experiments. Complex I- (CI-) mediated Leak (LEAK) respiration was determined using $2 \mathrm{mM}$ malate and $10 \mathrm{mM}$ glutamate. CI-mediated OXPHOS (OXPHOS) was determined using ADP (2.5 mM). Respiratory control ratios $\left(\mathrm{RCR}=\mathrm{CI}_{\text {OXPHOS }} / \mathrm{CI}_{\text {LEAK }}\right)$ were used as a quality control of isolated mitochondria. The convergent electron flow during the maximal OXPHOS respiration $\left(\mathrm{CI}+\mathrm{CII}_{\text {OXPHOS }}\right)$ was determined with substrates of CI and CII $(10 \mathrm{mM}$ Succinate). CI + CII-mediated ETS (electron transfer system) $\left(\mathrm{CI}+\mathrm{CII}_{\mathrm{ETS}}\right)$ was determined using Carbonyl cyanide-4-(trifluoromethoxy) phenylhydrazone (FCCP) (optimum concentration reached between 0.5 and $1.5 \mu \mathrm{M})$. CII-mediated ETS respiration $\left(\mathrm{CII}_{\mathrm{ETS}}\right)$ was determined with $0.5 \mu \mathrm{M}$ rotenone. Addition of $2.5 \mu \mathrm{M}$ antimycin A inhibited complex III, resulting in nonmitochondrial respiration (ROX) with small contributions from electron leak in the uncoupled state.

2.13. Western Blotting Analysis. Analysis of protein phosphorylation in cortical slices was performed using western blotting with slight modification [27]. Four slices were homogenized in $100 \mu \mathrm{L}$ of $4 \%$ SDS stop solution (4\% SDS, $50 \mathrm{mM}$ Tris, $100 \mathrm{mM}$ EDTA, pH 6.8), and $10 \mu \mathrm{L}$ of sample was taken out for protein analysis. In the remaining sample was added 25\% Glycerol sample and $8 \% \beta$-mercaptoethanol. The proteins were separated by SDS-PAGE using $10 \%$ gels and then electrotransferred to nitrocellulose membranes. The membranes were washed in Tris-buffered saline with Tween-20 (100 mM Tris- $\mathrm{HCl}, \mathrm{pH} 7.5,0.9 \% \mathrm{NaCl}$, and $0.1 \%$ Tween-20) and incubated overnight at $4^{\circ} \mathrm{C}$ with primary antibodies anti-phospho p38, anti-total and phosphoERK1/2, anti-total and phospho-JNK1/2, anti-phospho and total-AKT, anti-phospho PTEN. Subsequently, membranes were washed in Tris-buffered saline with Tween-20 and incubated for 1 hour at $25^{\circ} \mathrm{C}$ with horseradish peroxidase-linked anti-IgG secondary specific antibodies. The blottings were visualized on the IS4000MM Pro Bruker imaging system using ECL-detection reagent, and the band density was quantified using the Scion Image ${ }^{\circledR}$ software. The density of the bands was measured and expressed as a rate (\%) of increase in relation to control (slices treated only with media).

2.14. PI3K/AKT and MEK Inhibitors. To determine the implication of signaling pathway involved in cell survival in the neuroprotective effect of $A$. microcarpum methanolic fraction, PI3K/AKT inhibitor LY294002 at final concentration of $20 \mu \mathrm{M}$ and MEK/ERK inhibitor PD98059 at final concentration of $50 \mu \mathrm{M}$. PD98059 acts on inhibition of MEK1 in a reversible, allosteric, and noncompetitive manner with respect to ATP and ERK1/2 binding whereas LY294002 acts at an ATP-binding site of PI3K enzyme, thus selectively inhibiting the PI3K-Akt interaction. The inhibitors were added to the medium $30 \mathrm{~min}$ prior to the addition of 6 OHDA plus AMMF. After 2 hours of treatment, MTT assay was conducted to verify the slices viability as described above. Inhibitors were diluted in DMSO; the final concentration of DMSO in the wells was $0.5 \%$.

2.15. Protein Quantification. The protein concentration in samples was estimated using BSA as standard [28, 29].

2.16. Statistical Analysis. All data were tested for normal distribution by Kolmogorov-Smirnov. Statistical analysis was performed using one-way analysis of variance (ANOVA) followed by Newman-Keuls post hoc analysis. Results were considered statistically significant when $p<0.05$.

\section{Results}

3.1. Analysis of 6-Hydroxydopamine Autoxidation in the Presence of Extract and Fractions of A. microcarpum. 6-OHDA undergoes spontaneous autoxidation in the presence of oxygen under physiological conditions forming hydrogen peroxide $\left(\mathrm{H}_{2} \mathrm{O}_{2}\right)$ and the corresponding $p$-quinone whose formation can be monitored spectrophotometrically at $490 \mathrm{~nm}$ [10]. The absorbance of 6-OHDA at the end of 3 min of incubation with phosphate buffer is visualized in the graph (Figures $1(\mathrm{a})-1(\mathrm{c})$ ). The presence of fractions of A. microcarpum did not alter the 6-OHDA absorbance, whereas hydroalcoholic fraction decreased it partially. The antioxidant glutathione (GSH) was used as a positive control preventing 6-OHDA autoxidation due to the ability of 


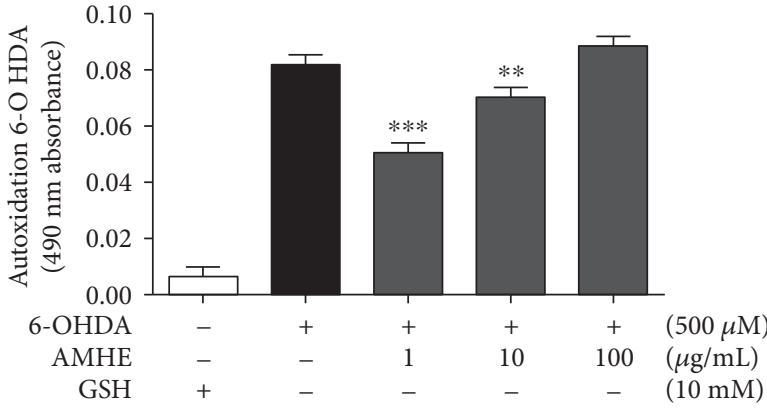

(a)

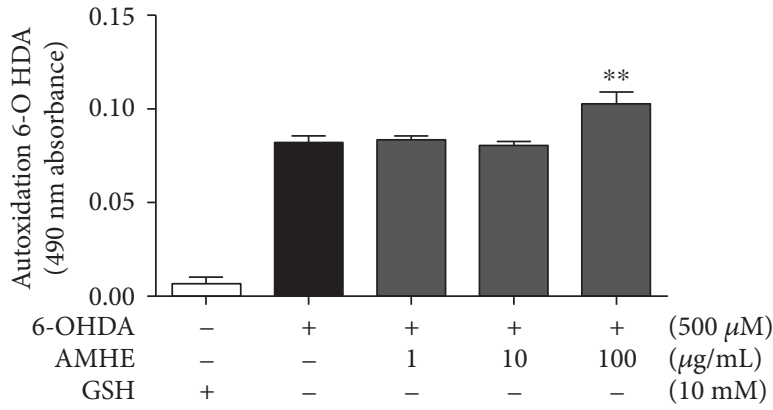

(b)

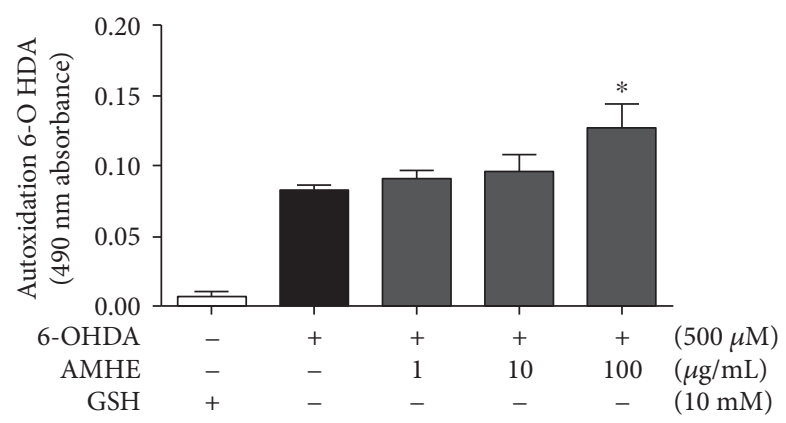

(c)

Figure 1: 6-OHDA autoxidation in the presence of $A$. microcarpum and GSH. The autoxidation of 6-OHDA (500 $\mu$ M) was followed spectrophotometrically by monitoring the formation of p-quinone at $490 \mathrm{~nm}$ in the presence or absence of extract or fractions (a) 6-OHDA + AMHE, (b) 6-OHDA + AMMF, and (c) 6-OHDA + AMEAF. GSH 10 mM was used as positive control preventing 6 -OHDA autoxidation. Data are expressed as percentage of the untreated control $\pm \mathrm{SE}(n=3) .{ }^{* * *} p<0.0001$ as compared to GSH control. $\# \# p<0.001$ and $\# \# \# p<0.0001$ as compared to 6-OHDA group.

sulfhydryl compounds to remove the $\mathrm{H}_{2} \mathrm{O}_{2}$ formed during the autoxidation reaction of 6-OHDA.

\subsection{Evaluation of Toxicity and Neuroprotective Potential of} A. microcarpum Hydroalcoholic Extract and Fractions. In order to investigate a possible neurotoxic effect of A. microcarpum, cortical slices were incubated for 2 hours with different concentrations of hydroalcoholic extract and fractions: 0 , $1 \mu \mathrm{g} / \mathrm{mL}, 10 \mu \mathrm{g} / \mathrm{mL}, 100 \mu \mathrm{g} / \mathrm{mL}$, and $1000 \mu \mathrm{g} / \mathrm{mL}$. At the end of incubation period, cell viability assay was performed by MTT test. Our data showed that A. microcarpum per se was unable to affect the viability of slices (Figures $2(a)-2(c)$ ).

To investigate the neuroprotective potential of A. microcarpum, slices were incubated with neurotoxin 6-OHDA $500 \mu \mathrm{M}$ for 2 hours in the presence or absence of different extracts or fraction concentration $(1-100 \mu \mathrm{g} / \mathrm{mL})$. 6-OHDA concentration was defined in a dose-response curve, and the concentration able to decrease in approximately 30\% the cell viability was chosen for further studies. The hydroalcoholic extract was unable to protect against damage caused by 6-OHDA (Figure 2(d)); however, AMMF and AMEAF reverted the drop in cell viability promoted by 6 -OHDA at a concentration of $100 \mu \mathrm{g} / \mathrm{mL}(p<0.0001)$ (Figures 2(e) and $2(\mathrm{f})$, respectively).

3.3. Lipid Peroxidation in Response to the Treatment with Methanolic and Acetate Fractions of A. microcarpum and 6-OHDA. Oxidative stress is implied in dopaminergic cell death induced by 6-OHDA [11]. AMMF and AMEAF but not AMHE presented neuroprotective potential in the MTT assay; thus, it was investigated a possible antioxidant potential of these fraction on slices exposed to 6-OHDA by its ability to prevent lipid peroxidation. 6-OHDA induced lipid peroxidation in $25 \%(p<0.0001)$ when compared to control group. Only AMMF prevented this effect (Figures 3(a) and $3(b))$; thus, further studies were conducted in the presence of methanolic fraction.

3.4. Analysis of ERK, AKT, PTEN Phosphorylation, and PARP Cleavage in Response to the Treatment with 6-OHDA and Methanolic Fraction of A. microcarpum. In this study, the effect of 6-OHDA on phosphorylation of proteins p38, JNK1/2, ERK1/2, AKT, cleavage of PARP protein, and phosphatase PTEN was analyzed by western blotting technique. No alterations in phosphorylation and total levels of p38 and JNK1/2 were detected (data not shown). The phosphorylation of ERK was increased in $30 \%$ only in the presence of extract and 6-OHDA (Figure 4(b)); no alterations were observed in the other groups. AKT phosphorylation (Figure $4(\mathrm{c})$ ) was inhibited in approximately $25 \%$ by 6 OHDA treatment and remained at control level when fraction was present. The cleavage of PARP protein in an $89 \mathrm{kDa}$ fragment was evaluated as an indicator of apoptotic cell death. No alteration in PARP cleavage was visualized by treatments as observed in the blotting. PTEN phosphorylation was unchanged by the treatments (Figure 4(d)). 


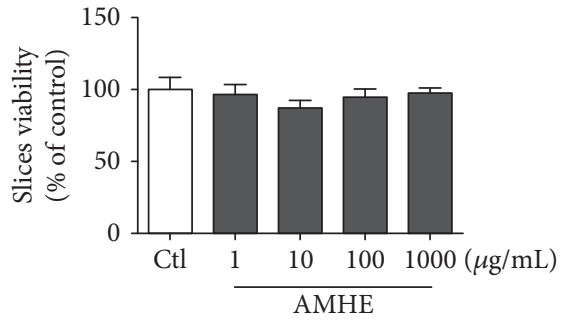

(a)

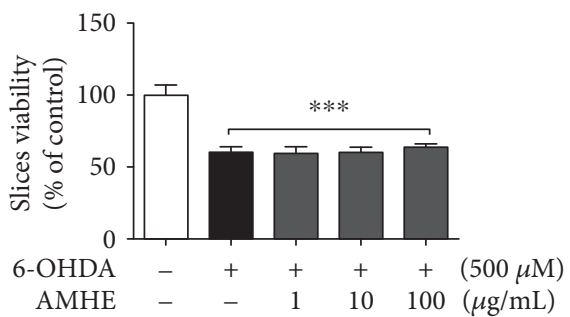

(d)

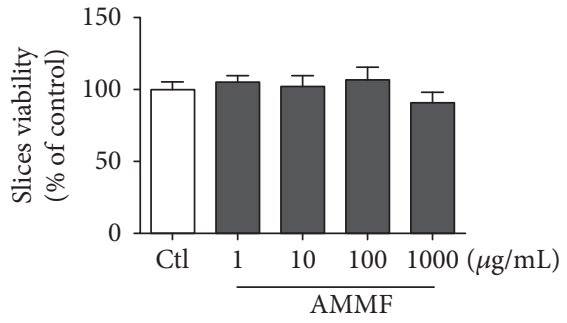

(b)

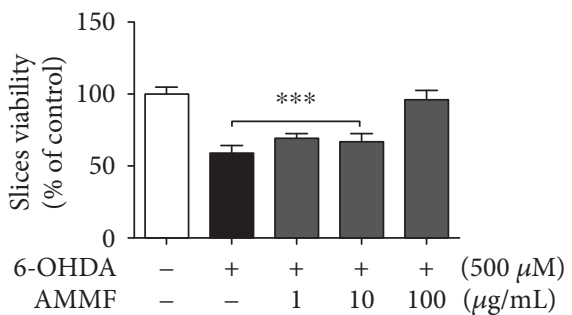

(e)

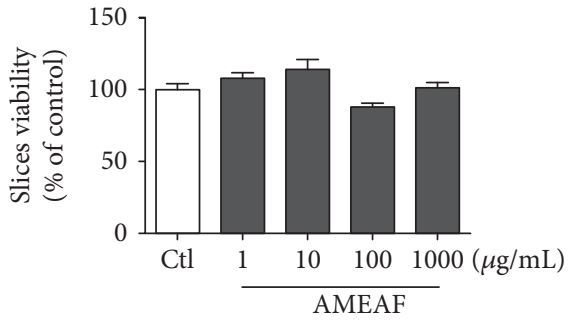

(c)

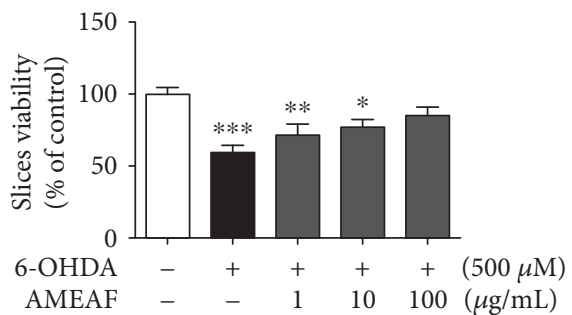

(f)

Figure 2: Effects of A. microcarpum and 6-OHDA on the viability of cortical slices. Cortical slices were incubated for $2 \mathrm{~h}$ in different concentrations (1-1000 $\mu \mathrm{g} / \mathrm{mL}$ ) of (a) AMHE, (b) AMMF, and (c) AMEAF and in the presence or absence of 6-OHDA (500 $\mu \mathrm{M}$ ) during $2 \mathrm{~h}$, (d) AMHE, (e) AMMF, and (f) AMEAF. Cell viability was measured by MTT test. Data are expressed as percentage of the untreated control $\pm \operatorname{SEM}(n=3) .{ }^{*} p<0.05,{ }^{* *} p<0.001$, and ${ }^{* * *} p<0.0001$ different from control group.

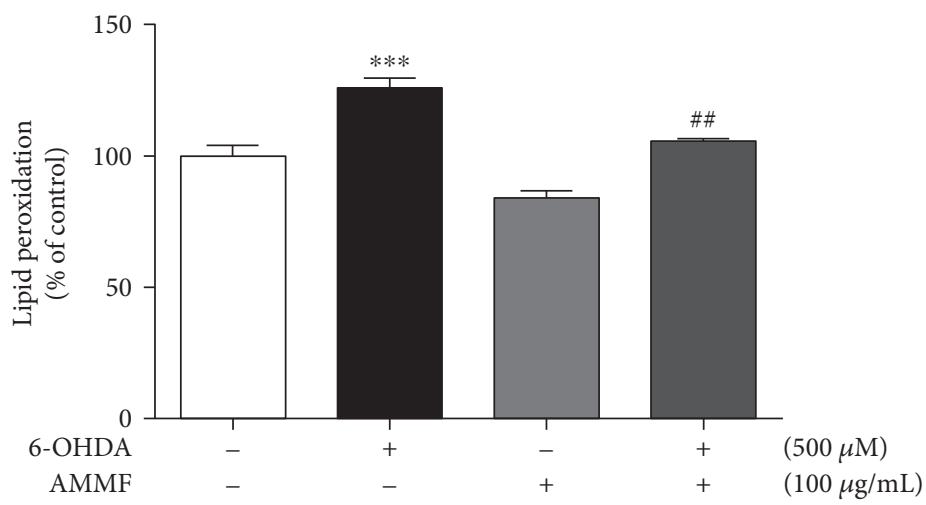

(a)

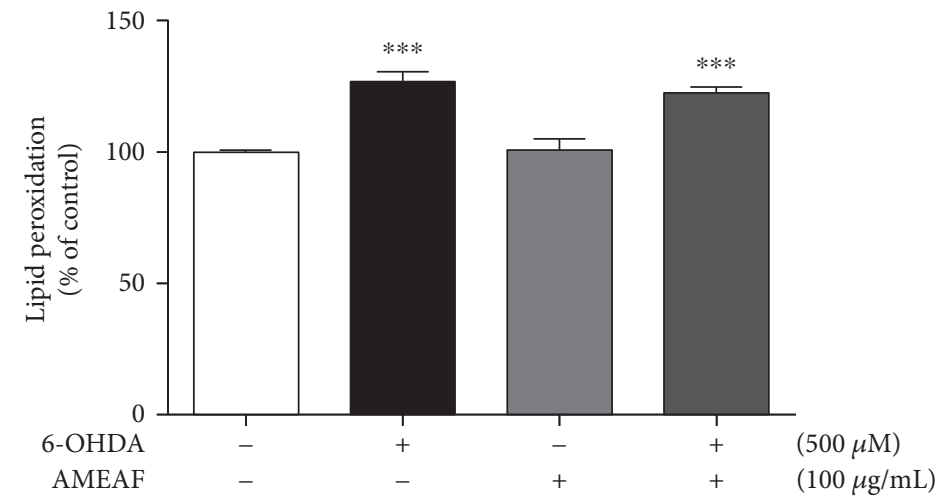

(b)

Figure 3: Effects of A. microcarpum on 6-OHDA $(500 \mu \mathrm{M})$ induced lipid peroxidation (LPO) in cortical slices. Cortical slices were incubated with (a) AMMF and (b) AMEAF in the presence/absence of 6-OHDA for two hours, and lipid peroxidation was evaluated by formation of TBARS at $532 \mathrm{~nm}$. Data are expressed as percentage of the untreated control \pm SEM $(n=3)$. ${ }^{* * *} p<0.0001$ as compared to control. $\# \#<0.001$ as compared to 6-OHDA group. 


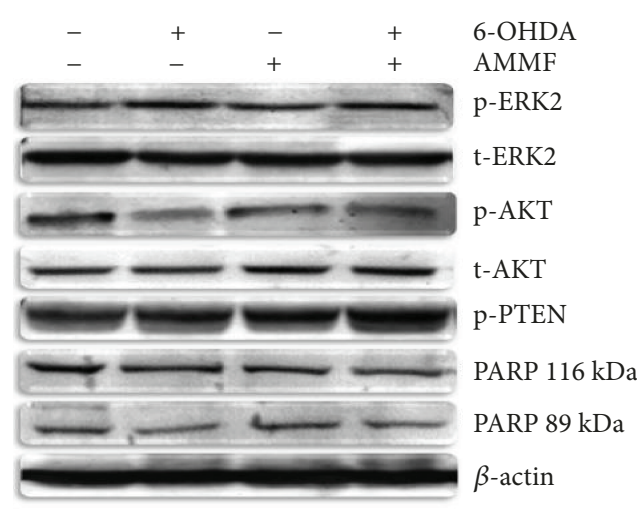

(a)

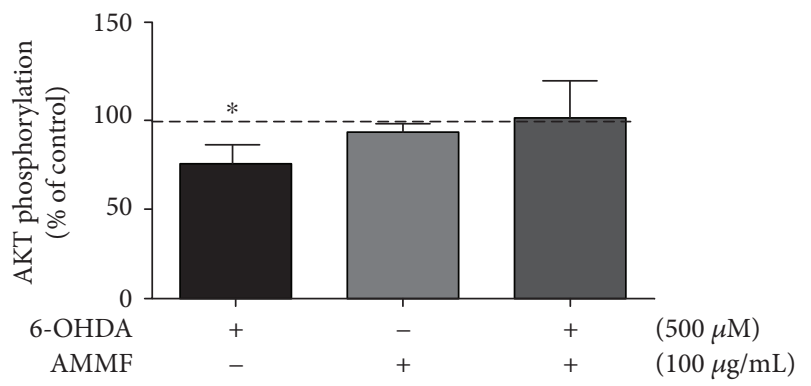

(c)

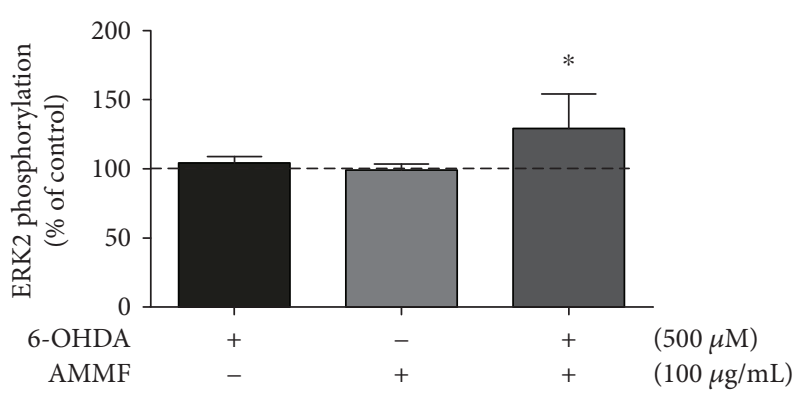

(b)

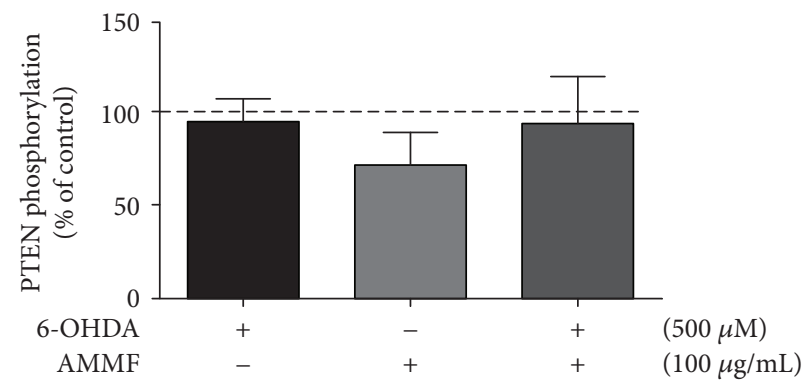

(d)

FIgure 4: Modulation of ERK, AKT and PTEN phosphorylation, PARP cleavage in response to treatment with methanolic fraction of A. microcarpum and 6-OHDA in cortical slices. Proteins were separated by SDS-PAGE and transferred to nitrocellulose membrane. Total content and phosphorylation of proteins were detected by specific antibodies, and the reaction was developed by ECL. (a) Western blotting of phosphorylated and total forms of ERK2 and AKT phosphorylation and total forms and phospho-PTEN. (b) Quantitative analysis of ERK2 phosphorylation expressed as a ratio with its respective total form. (c) Quantitative analysis of AKT phosphorylation expressed as a ratio with its respective total form. (d) Quantitative analysis of PTEN phosphorylation expressed as a ratio with $\beta$-actin. The data are expressed as fold increase related to control group and represent mean \pm SE of 4 independent experiments. Statistical analysis was performed by ANOVA, followed by the Newman-Keuls test. ${ }^{*} p<0.05,{ }^{* *} p<0.001$, and ${ }^{* * *} p<0.0001$ different from control group.

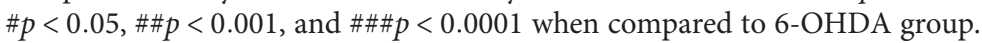

3.5. Involvement of ERK and AKT Signaling Pathways in the Neuroprotective Mechanisms of Fraction. The participation of ERK1/2 and AKT in the protective potential of the methanolic fraction was investigated. Slices were incubated with synthetic inhibitors of ERK1/2 phosphorylation (PD98059) and AKT phosphorylation (LY294002) for $30 \mathrm{~min}$ prior to the addition of 6-OHDA or methanolic fraction. As shown in Figure 5, the inhibition of ERK and AKT blocked the protective effects of extract.

3.6. Activity of Antioxidant Enzymes and Redox State of Cells in Response to the Treatment with the Methanolic Fraction of A. microcarpum and 6-OHDA. As shown in Table 2, 6OHDA caused a 1.68-fold increase in GST activity, and this effect was not observed in the presence of methanolic fraction and 6-OHDA. 6-OHDA induced TRx-R activity in 1.9-fold; this effect was not observed in the presence of methanolic fraction. On the other hand, GPx was inhibited in 1.71-fold by 6-OHDA when comparing to control, and this effect was not observed in the presence of methanolic fraction. The total glutathione content and oxidized glutathione were decreased by $34 \%$ and $39 \%$, respectively, by 6-OHDA treatment, and the ratio GSH/GSSG was increased by 6-OHDA. This effect was not observed when 6-OHDA was present. The plant per se increased levels of reduced GSH (Table 3).

3.7. Mitochondrial Respiration in Response to 6-OHDA and A. microcarpum Methanolic Fraction. The mitochondrial respiration in response to 6-OHDA and methanolic fraction was measured in brain homogenate by cellular oxygen consumption. Basal respiration was unchanged in the brain by treatments (data not shown). After glutamate and malate substrate $\left(\mathrm{CI}_{\text {Leak }}\right)$ addition, a significant decrease $(p<0.05)$ on $\mathrm{CI}$ activity was induced by $6-\mathrm{OHDA}$. This drop in $\mathrm{CI}$ activity persisted when methanolic fraction was added $(p<0.05)$. AMMF per se did not change the activity of CI. In order to see $\mathrm{CI}_{\mathrm{OxPHOS}}$, it was added succinate and $\mathrm{ADP}$ ( $\left.\mathrm{CI}_{\mathrm{OXPHOS}}\right)$; this parameter was also inhibited by 6-OHDA, and the fraction was unable to avoid it. The convergent electron flow during the maximal oxidative phosphorylation $\left(\mathrm{CI}+\mathrm{CII}_{\text {OXPHos }}\right)$ was also significantly decreased by 6OHDA, and the fraction did not avoid this effect. Maximal mitochondrial respiration $\left(\mathrm{CI}+\mathrm{CII}_{\mathrm{ETS}}\right)$ was determined with 


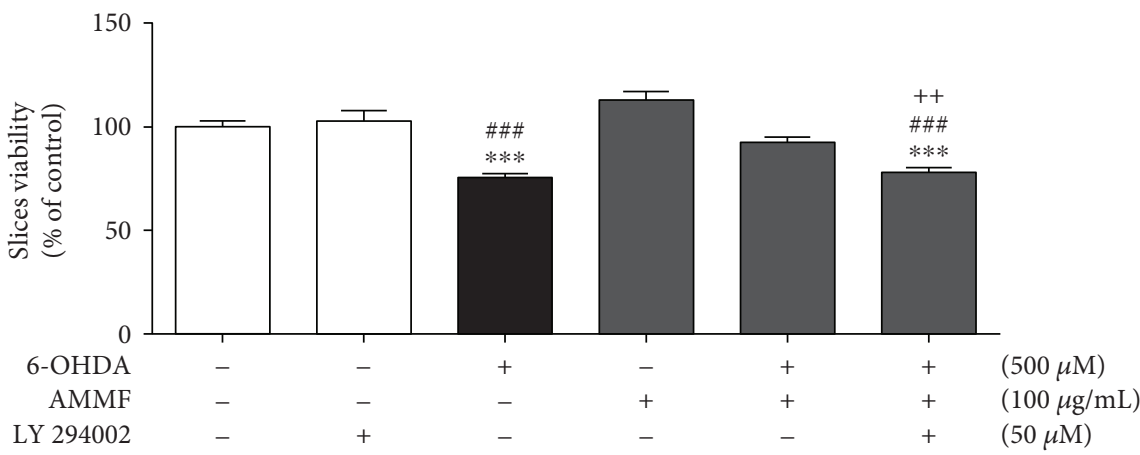

(a)

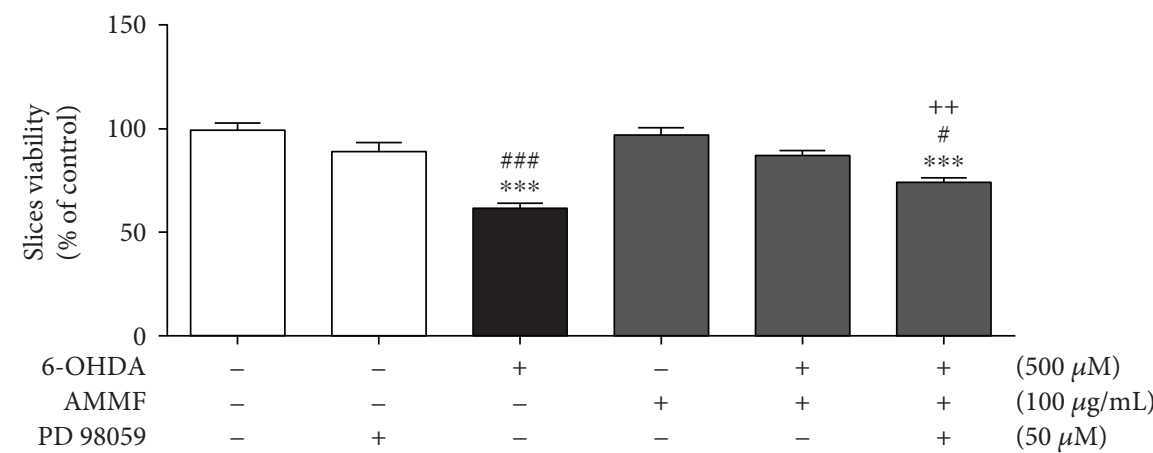

(b)

FIGURE 5: Effects of A. microcarpum and 6-OHDA on the viability of cortical slices in the presence of LY (294002) inhibitors and PD (98059). Slices were incubated with AMMF in the presence or absence of 6-OHDA $(500 \mu \mathrm{M})$ and inhibitors for $2 \mathrm{~h}$. The inhibitors were added 30 min prior to the addition of fraction and 6-OHDA and remained during all period of the treatment. Data are expressed as percentage of the

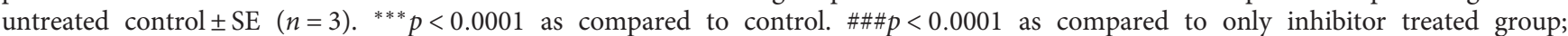
$++p<0.001$ as compared to cotreated group 6-OHDA + AMMF.

TABle 2: Activity of antioxidant enzymes in cortical slices submitted to treatment with the neurotoxin 6-OHDA and A. microcarpum methanolic fraction.

\begin{tabular}{lccc}
\hline & $\begin{array}{c}\text { GST } \\
(\mathrm{mg} / \mathrm{mU} \text { protein })\end{array}$ & $\begin{array}{c}\text { GPx } \\
\text { (mg/mU protein) }\end{array}$ & $\begin{array}{c}\text { TrxR } \\
(\mathrm{mg} / \mathrm{mU} \text { protein) }\end{array}$ \\
\hline Control & $241.2 \pm 8.49$ & $41.37 \pm 5.01$ & $2.375 \pm 0.342$ \\
6-OHDA $500 \mu \mathrm{M}$ & $406.4 \pm 75.89^{*}$ & $23.82 \pm 2.07^{*}$ & $4.675 \pm 0.608^{*}$ \\
AMMF $100 \mu \mathrm{g} / \mathrm{mL}$ & $186.2 \pm 42.13^{\#}$ & $51.01 \pm 4.04$ & $2.459 \pm 0.137^{\# \#}$ \\
AMMF $100 \mu \mathrm{g} / \mathrm{mL}+$ 6-OHDA $500 \mu \mathrm{M}$ & $251.5 \pm 36.48^{\#}$ & $46.29 \pm 3.20^{\# \#}$ & $3.164 \pm 0.496^{\#}$ \\
\hline
\end{tabular}

Data are expressed as percentage of the untreated control \pm SEM. ${ }^{*} p<0.05$ in relation to control group, \# $p<0.05$ in relation to control group, \#\# $p<0.001$ in relation to 6-OHDA group.

TABLE 3: Effect of treatment with 6-OHDA and A. microcarpum on GSH and GSSG levels and ratio GSH/GSSG.

\begin{tabular}{lcccc}
\hline & $\begin{array}{c}\text { GSH } \\
\text { (\% of control) }\end{array}$ & $\begin{array}{c}\text { GSSG } \\
\text { (\% of control) }\end{array}$ & $\begin{array}{c}\text { Total glutathione } \\
\text { (\% of control) }\end{array}$ & $\begin{array}{c}\text { GSH/GSSG } \\
\text { (\% of control) }\end{array}$ \\
\hline Control & $88.05 \pm 6.73$ & $90.60 \pm 5.48$ & $100.0 \pm 10.66$ & $100.0 \pm 2.51$ \\
6-OHDA $500 \mu \mathrm{M}$ & $87.49 \pm 5.41$ & $61.61 \pm 12.87^{*}$ & $66.56 \pm 11.34^{*}$ & $168.1 \pm 19.64^{* *}$ \\
AMMF $100 \mu \mathrm{g} / \mathrm{mL}$ & $136.7 \pm 6.54^{* *}$ & $117.2 \pm 10.04^{\# \#}$ & $129.7 \pm 4.18^{\# \#}$ & $120.7 \pm 9.21^{\# \#}$ \\
AMMF $100 \mu \mathrm{g} / \mathrm{mL}+$ 6-OHDA $500 \mu \mathrm{M}$ & $111.4 \pm 13.28$ & $111.9 \pm 3.17^{\# \#}$ & $111.8 \pm 4.96^{\#}$ & $99.61 \pm 8.99^{\# \#}$ \\
\hline
\end{tabular}

Data are expressed as percentage of the untreated control \pm SEM. ${ }^{*} p<0.05 ;{ }^{* *} p<0.001$ in relation to control group. \#\# $p<0.001$ when compared to 6-OHDA group. 


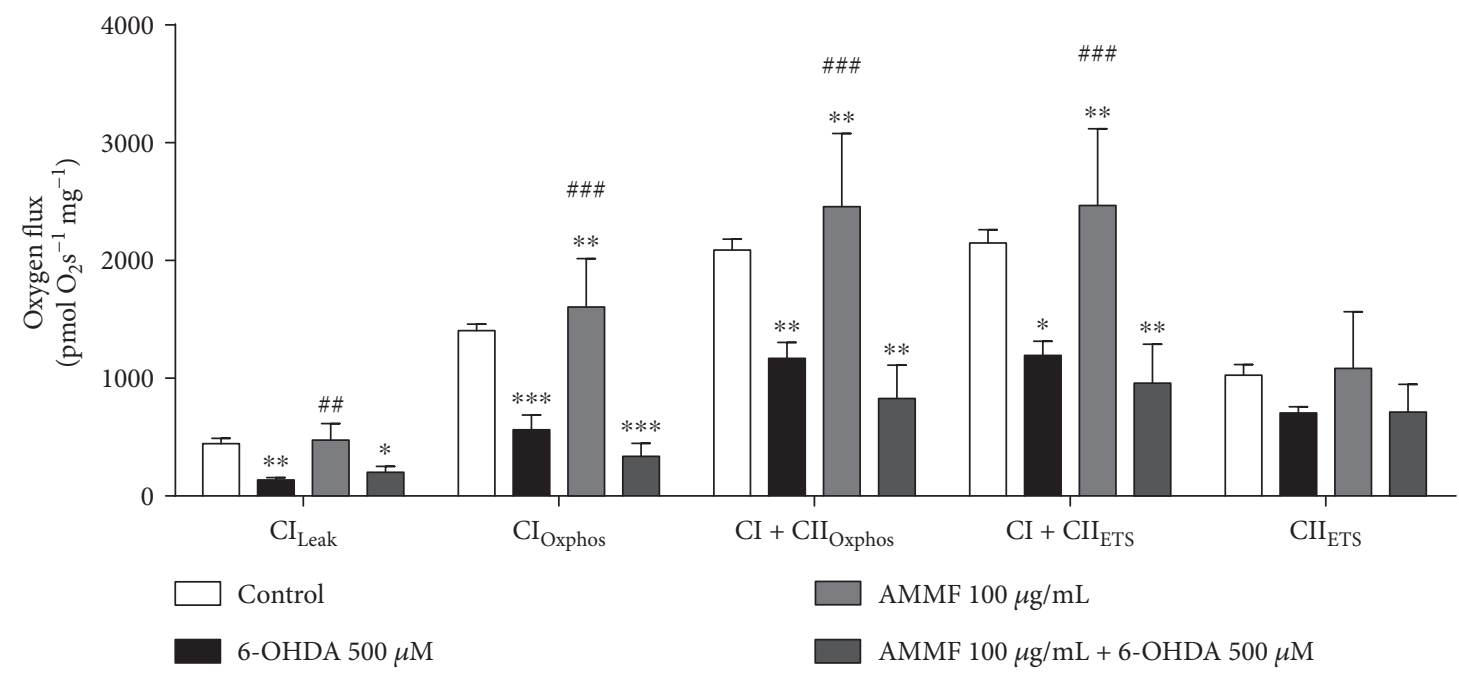

FIGURE 6: $\mathrm{O}_{2}$ flux measured in the mitochondria of cortex homogenate exposed to 6-OHDA and/or A. microcarpum. Mitochondrial function is presented with the abbreviation(s) of the complex(es) involved followed by the state of respiration measured in the presence of glutamate + malate $\left(\mathrm{CI}_{\mathrm{LEAK}}\right),+\mathrm{ADP}\left(\mathrm{CI}_{\mathrm{OXPHOS}}\right)$, + succinate $\left(\mathrm{CII}_{\mathrm{OXPHOS}}\right),+\mathrm{FCCP}\left(\mathrm{CI}+\mathrm{II}_{\mathrm{ETS}}\right)$, +rotenone $\left(\mathrm{CII}_{\mathrm{ETS}}\right)$. Antimycin A was used to correct for residual $\mathrm{O}_{2}$ consumption. Results are means \pm SEM for 4 different preparations. ${ }^{*} p<0.05,{ }^{* *} p<0.001$, and ${ }^{* * *} p<0.0001$

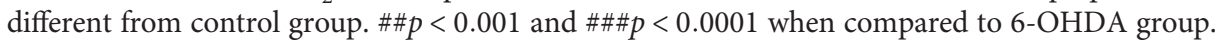

the addition of the uncoupler FCCP. This parameter was inhibited by $6-$ OHDA and not avoided by the fraction $(p<0.001)$. $\mathrm{CII}_{\mathrm{ETS}}$ activity was analyzed after inhibition of $\mathrm{CI}$ by rotenone, and no significant changes occurred by treatments. AMMF per se but not in the presence of 6-OHDA induced $\mathrm{CI}_{\mathrm{LEAK}}, \mathrm{CI}_{\mathrm{OXPHOS}}, \mathrm{CI}+\mathrm{CII}_{\mathrm{OXPHOS}}$, and $\mathrm{CI}+\mathrm{II}_{\mathrm{ETS}}$ (Figure 6).

\section{Discussion}

Oxidative stress, mitochondrial dysfunction, genetic, and environmental factors are mechanisms associated with neuronal damage observed in PD [30-32]. A number of studies have proposed antioxidant therapies to attenuate PD symptoms $[33,34]$. In this study, methanolic and acetate fraction but not hydroalcoholic extract protected against neurotoxicity induced by 6-OHDA in brain slices, but methanolic fraction was more effective in protecting against induction in lipid peroxidation by 6-OHDA.

The cytotoxic effect of 6-OHDA is attributed to the formation of reactive species such as superoxide radical, para-quinone, and hydrogen peroxide from enzymatic and autoxidation reactions [35]. It this study, plant extract or fractions did not block effectively the autoxidation of 6OHDA in vitro. With the base in this finding, it can be inferred that the mechanism implied in the protective effect of the plant is the neutralization of reactive species secondary to the autoxidation reaction and not a direct interaction with 6-OHDA molecule. In previous studies, 6-OHDA induced mitochondrial dysfunction by inhibition of I and IV complexes, disrupting the mitochondrial function, and producing superoxide anion, which in turn may form hydroxyl radicals which reacts with nitric oxide generating peroxynitrite [36-39]. In the present study, the 6-OHDA inhibited in $55 \%$ complex I activity in basal respiration around $75 \%$ the ATP production CI-dependent and compromise the mitochondrial electron transport system in $50 \%$. This is in accordance with a similar work that showed a $20 \%$ of inhibition of complex I at a concentration of $100 \mu \mathrm{M}$, approximately [40]. This phenomenon was not blocked by A. microcarpum. Considering the inability of the plant to hamper the mitochondrial damage caused by 6-OHDA, it could be supposed that the neuroprotective effect by the plant is due to the neutralization of reactive species resulted from mitochondrial dysfunction.

Reactive oxygen species production, detoxification, and signaling pathways have been considered interesting targets for intervention in neurodegenerative diseases [41, 42]. Endogenous enzymatic and nonenzymatic antioxidants, such as GSH, glutathione S-transferase, glutathione peroxidase, and thioredoxin reductase (TRx-R), delay or prevent oxidative damage to proteins, lipids, and DNA [43, 44]. Glutathione peroxidase $(\mathrm{GPx})$ is an intracellular antioxidant that reduces hydrogen peroxide to water at expenses of GSH and limits its harmful effect. In this study, 6-OHDA caused a substantial inhibition in GPx activity that was not observed in presence of methanolic fraction. Similar data were demonstrated in neuroblastoma cells treated with 6-OHDA [45]. In PD patients, the degree of symptom severity correlates with intracellular GSH loss in substantia nigra [46]. In our study, GSH content was not altered, and GSSG was decreased by 6-OHDA; this effect may be related to GPx inhibition and consequently a lower oxidation of GSH by this system. On the other hand, the TRx-R activity was stimulated by 6 OHDA, and the same data were observed in neuroblastoma cell line SH-SY5Y [47]. Our results suggest the participation of peroxiredoxins catalyzing peroxide reduction as a compensatory mechanism to replace the inhibited activity of GPx. Herein, 6-OHDA increased the activity of GST, which is implied in neuronal detoxification of quinones resulted 
from catecholamine oxidation and free radicals [48], and this effect was not observed when plant was present. All these effects were prevented by the methanolic fraction of plant, showing a protective mechanism against oxidative stress induced by the 6-OHDA. Due to methodological issues, we were not able to detect quantifiable levels of the enzymes Superoxide Dismutase and Catalase, but their analysis will be considered in further studies.

Extracellular signal-regulated kinases (ERKs) have been implicated in the cellular response to reactive oxygen species [49-52]. Growth factors and other extracellular stimuli activate the kinase MEK1/2 by Ras/Raf pathway; MEK1/2 then phosphorylates and activates ERK1/2 [53]. ERK1/2 activates transcription factors such as cAMP response element-binding protein (CREB) and Elk, thereby increasing transcription of neurotrophic factors and prosurvival genes such as Bcl-2 [54]. In this study, the use of MEK1/2 inhibitor weakened the protective potential of methanolic fraction against the 6-OHDA, suggesting that the antioxidant potential of fraction per se is not enough to protect the brains slices, but the activation of prosurvival factors plays an important role in this effect. Experiments of western blotting showed that 6-OHDA did not alter ERK phosphorylation in brain slices after two hours of incubation with 6-OHDA. Previous studies reported an ERK1/2 phosphorylation peak after $10-15 \mathrm{~min}$ of exposure of dopaminergic cells to 6OHDA; the phosphorylation of prosurvival protein CREB followed this temporal profile as well [54]. Authors showed that the inhibition of early phosphorylation of ERK1/2 abolished CREB activation and increased 6-OHDA toxicity. Thus, the possibility of an early activation of ERK1/2 in slices submitted to the treatment and the contribution of this activation for a self-protective response of cells that was prevented with use of inhibitors could not be discarded.

AKT is a serine/threonine kinase and its signaling pathway plays an important role in fundamental cellular functions, such as cell proliferation and survival, by phosphorylating a variety of enzymes, including proapoptotic regulators, antioxidant proteins, and transcription factors [55]. It is reported that AKT phosphorylation is reduced in the striatum of patients with $\mathrm{PD}$, suggesting that its inactivation has an important role in PD [56]; being so, it is a substantial therapeutic target for treating neurodegenerative diseases, beyond other pathologies [57]. Herein, 6-OHDA inhibited phosphorylation level of AKT, and the plant prevented this effect. There was no alteration in phosphorylation level of PTEN (Phosphatase and tensin homolog deleted on chromosome ten), a negative regulator of AKT. Similar results were reported in SH-SY5Y and dopaminergic cell lines $[58,59]$. In this study, AKT phosphorylation seems to display a role in neuroprotective effect of fraction against 6-OHDA, once the use of PI3K/AKT inhibitor blocked the protective effect of fraction. This result proposes that survival signaling pathways ERK and AKT contribute for neuroprotection by methanolic fraction of $A$. microcarpum.

Recent studies have suggested that several signal transduction pathways, including phosphatidylinositol 3 kinase (PI3K) pathways and MAPKs, are involved in releasing transcription factor Nrf2 from the complex Keap1-Nrf2 promoting Nfr2 translocation to the nucleus [60]. Nrf2 promotes transcriptional activation of a variety of antioxidant genes [61]. AMMF-mediated cytoprotection against 6OHDA was abolished by ERK and AKT pathway inhibitors; these data support a possible involvement of Nrf2 activation leading to expression of downstream antioxidant genes through the modulation of AKT and ERK1/2 pathways by the fraction. According to another study, inhibition of AKT and ERK has also abolished the neuroprotective effect of a triterpenoid isolated from plant [62].

\section{Conclusion}

The present work shows for the first time the potential of the Brazilian plant A. microcarpum in protecting against 6-OHDA-induced damage in brain slices. Inhibition of mitochondrial complexes by 6-OHDA was not avoided by the extract. ERK and AKT phosphorylation display a role in the neuroprotective effect by the plant which was decreased by the presence of pharmacological inhibitors of those pathways.

\section{Data Availability}

The data used to support the findings of this study are available from the corresponding author upon request.

\section{Conflicts of Interest}

The authors declare that they have no conflicts of interest.

\section{Acknowledgments}

This study was supported by CNPq process \#456207/2014-7, FAPERGS process \# 2380-2551/14-8, and FAPERGS/ PRONEX \#16/25510000499-4. JLF is a recipient of CNPq fellowship. IKM, GEM and NRR are recipients of CAPES doctoral scholarship.

\section{References}

[1] V. M. B. Filho, E. P. Waczuk, J. P. Kamdem et al., "Phytochemical constituents, antioxidant activity, cytotoxicity and osmotic fragility effects of Caju (Anacardium microcarpum)," Industrial Crops and Products, vol. 55, pp. 280-288, 2014.

[2] H. Coutinho, V. Barbosa-Filho, E. Waczuk et al., "Phytocompounds and modulatory effects of Anacardium microcarpum (cajui) on antibiotic drugs used in clinical infections," Drug Design, Development and Therapy, vol. 9, pp. 5965-5972, 2015.

[3] T. Fritsch, K. A. Smyth, M. S. Wallendal, T. Hyde, G. Leo, and D. S. Geldmacher, "Parkinson disease: research update and clinical management," Southern Medical Journal, vol. 105, no. 12, pp. 650-656, 2012.

[4] R. Balestrino and P. Martinez-Martin, "Neuropsychiatric symptoms, behavioural disorders, and quality of life in Parkinson's disease," Journal of the Neurological Sciences, vol. 373, pp. 173-178, 2017.

[5] P. P. Michel, E. C. Hirsch, and S. Hunot, "Understanding dopaminergic cell death pathways in Parkinson disease," Neuron, vol. 90, no. 4, pp. 675-691, 2016. 
[6] S. Fahn and D. Sulzer, "Neurodegeneration and neuroprotection in Parkinson disease," NeuroRx, vol. 1, no. 1, pp. 139154, 2004.

[7] P. Bhattarai, A. K. Thomas, Y. Zhang, and C. Kizil, "The effects of aging on amyloid- $\beta 42$-induced neurodegeneration and regeneration in adult zebrafish brain," Neurogenesis, vol. 4, no. 1, article e1322666, 2017.

[8] D. Kempuraj, R. Thangavel, P. A. Natteru et al., "Neuroinflammation induces neurodegeneration," Journal of Neurology, Neurosurgery and Spine, vol. 1, no. 1, 2016.

[9] J. Bové and C. Perier, "Neurotoxin-based models of Parkinson's disease," Neuroscience, vol. 211, pp. 51-76, 2012.

[10] R. Soto-Otero, E. Méndez-Álvarez, Á. Hermida-Ameijeiras, A. M. Muñoz-Patiño, and J. L. Labandeira-Garcia, "Autoxidation and neurotoxicity of 6-hydroxydopamine in the presence of some antioxidants: potential implication in relation to the pathogenesis of Parkinson's disease," Journal of Neurochemistry, vol. 74, no. 4, pp. 1605-1612, 2000.

[11] M. Shichiri, "The role of lipid peroxidation in neurological disorders," Journal of Clinical Biochemistry and Nutrition, vol. 54, no. 3, pp. 151-160, 2014.

[12] D. Blum, S. Torch, N. Lambeng et al., "Molecular pathways involved in the neurotoxicity of 6-OHDA, dopamine and MPTP: contribution to the apoptotic theory in Parkinson's disease," Progress in Neurobiology, vol. 65, no. 2, pp. 135$172,2001$.

[13] K. Komolafe, T. M. Olaleye, R. L. Seeger et al., "Parkia biglobosa improves mitochondrial functioning and protects against neurotoxic agents in rat brain hippocampal slices," BioMed Research International, vol. 2014, Article ID 326290, 15 pages, 2014.

[14] K. Gao, M. Liu, J. Cao et al., "Protective effects of Lycium barbarum polysaccharide on 6-OHDA-induced apoptosis in PC12 cells through the ROS-NO pathway," Molecules, vol. 20, no. 1, pp. 293-308, 2015.

[15] A. I. Abushouk, A. Negida, H. Ahmed, and M. M. AbdelDaim, "Neuroprotective mechanisms of plant extracts against MPTP induced neurotoxicity: future applications in Parkinson's disease," Biomedicine \& Pharmacotherapy, vol. 85, pp. 635-645, 2017.

[16] R. Rodnight, C. A. Gonçalves, R. Leal, E. Rocha, C. G. Salbego, and S. T. Wofchuk, "Chapter 11: regional distribution and properties of an enzyme system in rat brain that phosphorylates $\mathrm{ppH}-47$, an insoluble protein highly labelled in tissue slices from the hippocampus," Progress in Brain Research, vol. 89, pp. 157-167, 1991.

[17] T. Posser, J. L. Franco, D. A. dos Santos et al., "Diphenyl diselenide confers neuroprotection against hydrogen peroxide toxicity in hippocampal slices," Brain Research, vol. 1199, pp. 138-147, 2008.

[18] H. Ohkawa, N. Ohishi, and K. Yagi, “Assay for lipid peroxides in animal tissues by thiobarbituric acid reaction," Analytical Biochemistry, vol. 95, no. 2, pp. 351-358, 1979.

[19] W. H. Habig and W. B. Jakoby, "[51] Assays for differentiation of glutathione S-transferases," Methods in Enzymology, vol. 77, pp. 398-405, 1981.

[20] A. Wendel, "[44] Glutathione peroxidase," Methods in Enzymology, vol. 77, pp. 325-333, 1981.

[21] A. Holmgren and M. Björnstedt, "Thioredoxin and thioredoxin reductase," Methods in Enzymology, vol. 252, pp. 199208, 1995.
[22] P. J. Hissin and R. Hilf, "A fluorometric method for determination of oxidized and reduced glutathione in tissues," Analytical Biochemistry, vol. 74, no. 1, pp. 214-226, 1976.

[23] E. Gnaiger, "Capacity of oxidative phosphorylation in human skeletal muscle: new perspectives of mitochondrial physiology," The International Journal of Biochemistry \& Cell Biology, vol. 41, no. 10, pp. 1837-1845, 2009.

[24] A. V. Kuznetsov, S. Schneeberger, R. Seiler et al., "Mitochondrial defects and heterogeneous cytochrome $c$ release after cardiac cold ischemia and reperfusion," American Journal of Physiology-Heart and Circulatory Physiology, vol. 286, no. 5, pp. H1633-H1641, 2004.

[25] N. Pichaud, M. Messmer, C. C. Correa, and J. W. O. Ballard, "Diet influences the intake target and mitochondrial functions of Drosophila melanogaster males," Mitochondrion, vol. 13, no. 6, pp. 817-822, 2013.

[26] D. Pesta and E. Gnaiger, "High-resolution respirometry: OXPHOS protocols for human cells and permeabilized fibers from small biopsies of human muscle," Methods in Molecular Biology, vol. 810, pp. 25-58, 2012.

[27] T. Posser, M. T. De Paula, J. L. Franco, R. B. Leal, and J. B. T. Da Rocha, "Diphenyl diselenide induces apoptotic cell death and modulates ERK1/2 phosphorylation in human neuroblastoma SH-SY5Y cells," Archives of Toxicology, vol. 85, no. 6, pp. 645-651, 2011.

[28] M. M. Bradford, "A rapid and sensitive method for the quantitation of microgram quantities of protein utilizing the principle of protein-dye binding," Analytical Biochemistry, vol. 72, no. 1-2, pp. 248-254, 1976.

[29] G. L. Peterson, "A simplification of the protein assay method of Lowry et al. which is more generally applicable," Analytical Biochemistry, vol. 83, no. 2, pp. 346-356, 1977.

[30] V. Bellou, L. Belbasis, I. Tzoulaki, E. Evangelou, and J. P. A. Ioannidis, "Environmental risk factors and Parkinson's disease: an umbrella review of meta-analyses," Parkinsonism \& Related Disorders, vol. 23, pp. 1-9, 2016.

[31] S. D. Ugarte, E. Lin, E. Klann, M. J. Zigmond, and R. G. Perez, "Effects of GDNF on 6-OHDA-induced death in a dopaminergic cell line: modulation by inhibitors of PI3 kinase and MEK," Journal of Neuroscience Research, vol. 73, no. 1, pp. 105-112, 2003.

[32] B. Uttara, A. Singh, P. Zamboni, and R. Mahajan, "Oxidative stress and neurodegenerative diseases: a review of upstream and downstream antioxidant therapeutic options," Current Neuropharmacology, vol. 7, no. 1, pp. 65-74, 2009.

[33] M. Solayman, M. Islam, F. Alam, M. Khalil, M. Kamal, and S. Gan, "Natural products combating neurodegeneration: Parkinson's disease," Current Drug Metabolism, vol. 18, no. 1, pp. 50-61, 2017.

[34] Q. Zhao, J. Ye, N. Wei, C. Fong, and X. Dong, "Protection against $\mathrm{MPP}^{+}$-induced neurotoxicity in SH-SY5Y cells by tormentic acid via the activation of PI3-K/Akt/GSK3 $\beta$ pathway," Neurochemistry International, vol. 97, pp. 117-123, 2016.

[35] Y. Glinka, M. Gassen, and M. B. H. Youdim, "Mechanism of 6-hydroxydopamine neurotoxicity," Journal of Neural Transmission. Supplementum, vol. 50, pp. 55-66, 1997.

[36] Y. Y. Glinka and M. B. H. Youdim, "Inhibition of mitochondrial complexes I and IV by 6-hydroxydopamine," European Journal of Pharmacology, vol. 292, no. 3-4, pp. 329-332, 1995.

[37] G. C. Brown and V. Borutaite, "Inhibition of mitochondrial respiratory complex I by nitric oxide, peroxynitrite and 
S-nitrosothiols," Biochimica et Biophysica Acta (BBA) Bioenergetics, vol. 1658, no. 1-2, pp. 44-49, 2004.

[38] R. K. Chaturvedi and M. Flint Beal, "Mitochondrial diseases of the brain," Free Radical Biology \& Medicine, vol. 63, pp. 1-29, 2013.

[39] M. Golpich, E. Amini, Z. Mohamed, R. Azman Ali, N. Mohamed Ibrahim, and A. Ahmadiani, "Mitochondrial dysfunction and biogenesis in neurodegenerative diseases: pathogenesis and treatment," CNS Neuroscience \& Therapeutics, vol. 23, no. 1, pp. 5-22, 2017.

[40] J. Iglesias-González, S. Sánchez-Iglesias, E. Méndez-Álvarez et al., "Differential toxicity of 6-hydroxydopamine in $\mathrm{SH}$ SY5Y human neuroblastoma cells and rat brain mitochondria: protective role of catalase and superoxide dismutase," Neurochemical Research, vol. 37, no. 10, pp. 2150-2160, 2012.

[41] E. K. Kim and E.-J. Choi, "Compromised MAPK signaling in human diseases: an update," Archives of Toxicology, vol. 89, no. 6, pp. 867-882, 2015.

[42] J. M. C. Gutteridge and B. Halliwell, “Antioxidants: molecules, medicines, and myths," Biochemical and Biophysical Research Communications, vol. 393, no. 4, pp. 561-564, 2010.

[43] J. Robaczewska, K. Kedziora-Kornatowska, M. Kozakiewicz et al., "Role of glutathione metabolism and glutathionerelated antioxidant defense systems in hypertension," Journal of Physiology and Pharmacology, vol. 67, no. 3, pp. 331337, 2016.

[44] H.-C. Kuo, H.-C. Chang, W.-C. Lan, F.-H. Tsai, J.-C. Liao, and C.-R. Wu, "Protective effects of Drynaria fortunei against 6-hydroxydopamine-induced oxidative damage in B35 cells via the PI3K/AKT pathway," Food \& Function, vol. 5, no. 8, pp. 1956-1965, 2014.

[45] Y. Chandrasekhar, G. Phani Kumar, E. M. Ramya, and K. R. Anilakumar, "Gallic acid protects 6-OHDA induced neurotoxicity by attenuating oxidative stress in human dopaminergic cell line," Neurochemical Research, vol. 43, no. 6, pp. 11501160, 2018.

[46] P. Riederer, E. Sofic, W. D. Rausch et al., "Transition metals, ferritin, glutathione, and ascorbic acid in parkinsonian brains," Journal of Neurochemistry, vol. 52, no. 2, pp. 515-520, 1989.

[47] L. Arodin, A. Miranda-Vizuete, P. Swoboda, and A. P. Fernandes, "Protective effects of the thioredoxin and glutaredoxin systems in dopamine-induced cell death," Free Radical Biology \& Medicine, vol. 73, pp. 328-336, 2014.

[48] A. P. Mazzetti, M. C. Fiorile, A. Primavera, and M. Lo Bello, "Glutathione transferases and neurodegenerative diseases," Neurochemistry International, vol. 82, pp. 10-18, 2015.

[49] K. Z. Guyton, Y. Liu, M. Gorospe, Q. Xu, and N. J. Holbrook, "Activation of mitogen-activated protein kinase by $\mathrm{H}_{2} \mathrm{O}_{2}$. Role in cell survival following oxidant injury," The Journal of Biological Chemistry, vol. 271, no. 8, pp. 4138-4142, 1996.

[50] A. Bonni, A. Brunet, A. E. West, S. R. Datta, M. A. Takasu, and M. E. Greenberg, "Cell survival promoted by the RasMAPK signaling pathway by transcription-dependent and -independent mechanisms," Science, vol. 286, no. 5443, pp. 1358-1362, 1999.

[51] H. Dudek, S. R. Datta, T. F. Franke et al., "Regulation of neuronal survival by the serine-threonine protein kinase Akt," Science, vol. 275, no. 5300, pp. 661-665, 1997.

[52] H. Harada, B. Quearry, A. Ruiz-Vela, and S. J. Korsmeyer, "Survival factor-induced extracellular signal-regulated kinase phosphorylates BIM, inhibiting its association with BAX and proapoptotic activity," Proceedings of the National Academy of Sciences, vol. 101, no. 43, pp. 15313-15317, 2004.

[53] R. Seger and E. G. Krebs, "The MAPK signaling cascade," The FASEB Journal, vol. 9, no. 9, pp. 726-735, 1995.

[54] E. Lin, J. E. Cavanaugh, R. K. Leak, R. G. Perez, and M. J. Zigmond, "Rapid activation of ERK by 6-hydroxydopamine promotes survival of dopaminergic cells," Journal of Neuroscience Research, vol. 86, no. 1, pp. 108-117, 2008.

[55] B. D. Manning and A. Toker, "AKT/PKB signaling: navigating the network," Cell, vol. 169, no. 3, pp. 381-405, 2017.

[56] L. A. Greene, O. Levy, and C. Malagelada, "Akt as a victim, villain and potential hero in Parkinson's disease pathophysiology and treatment," Cellular and Molecular Neurobiology, vol. 31, no. 7, pp. 969-978, 2011.

[57] M. P. Cunha, M. D. Martín-de-Saavedra, A. Romero et al., "Protective effect of creatine against 6-hydroxydopamineinduced cell death in human neuroblastoma SH-SY5Y cells: involvement of intracellular signaling pathways," Neuroscience, vol. 238, pp. 185-194, 2013.

[58] E. Amiri, R. Ghasemi, and M. Moosavi, "Agmatine protects against 6-OHDA-induced apoptosis, and ERK and Akt/GSK disruption in SH-SY5Y cells," Cellular and Molecular Neurobiology, vol. 36, no. 6, pp. 829-838, 2016.

[59] C. X. Tiong, M. Lu, and J.-S. Bian, "Protective effect of hydrogen sulphide against 6-OHDA-induced cell injury in SH-SY5Y cells involves PKC/PI3K/Akt pathway," British Journal of Pharmacology, vol. 161, no. 2, pp. 467-480, 2010.

[60] J. Kim, Y.-N. Cha, and Y.-J. Surh, "A protective role of nuclear factor-erythroid 2-related factor-2 (Nrf2) in inflammatory disorders," Mutation Research/Fundamental and Molecular Mechanisms of Mutagenesis, vol. 690, no. 1-2, pp. 12-23, 2010.

[61] S. E. Lacher, J. S. Lee, X. Wang, M. R. Campbell, D. A. Bell, and M. Slattery, "Beyond antioxidant genes in the ancient Nrf2 regulatory network," Free Radical Biology \& Medicine, vol. 88, pp. 452-465, 2015.

[62] Z. Qi, X. Ci, J. Huang et al., “Asiatic acid enhances Nrf2 signaling to protect HepG2 cells from oxidative damage through Akt and ERK activation," Biomedicine \& Pharmacotherapy, vol. 88, pp. 252-259, 2017. 


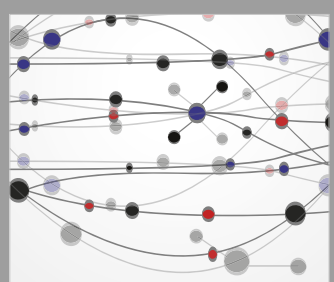

The Scientific World Journal
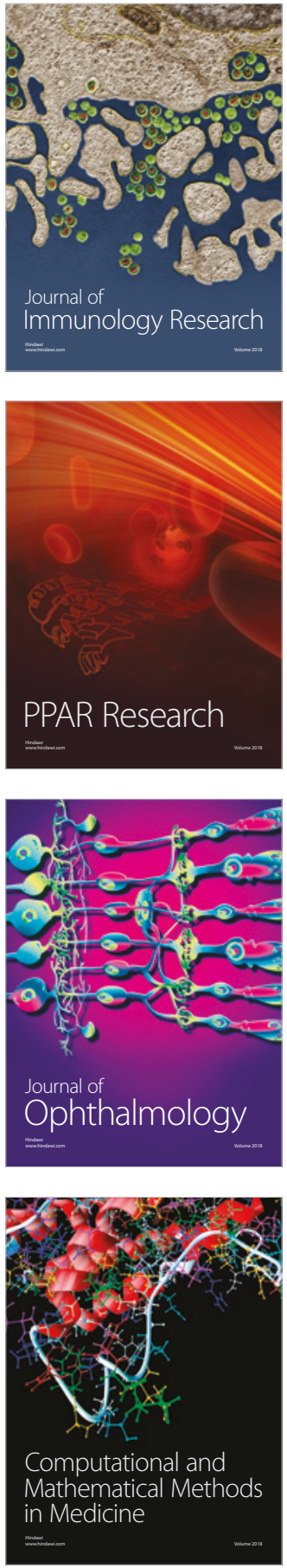

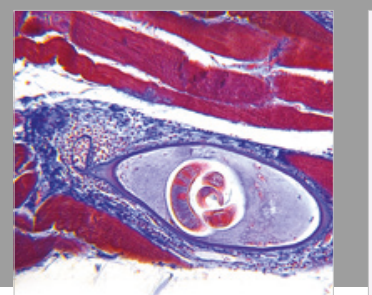

Gastroenterology Research and Practice

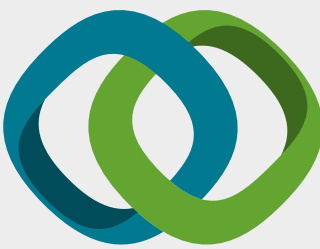

\section{Hindawi}

Submit your manuscripts at

www.hindawi.com
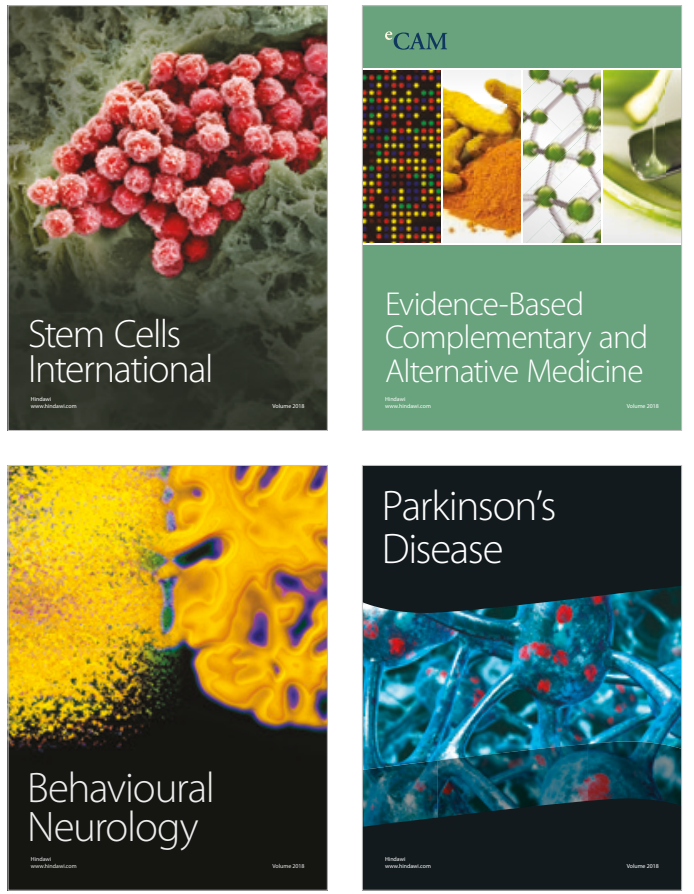

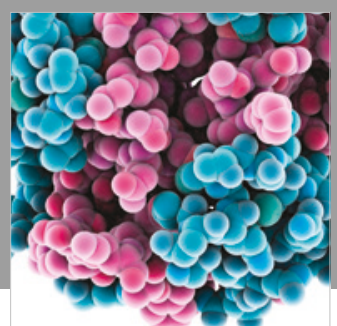

ournal of

Diabetes Research

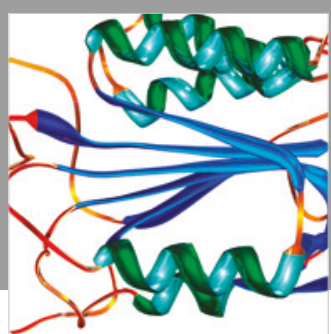

Disease Markers
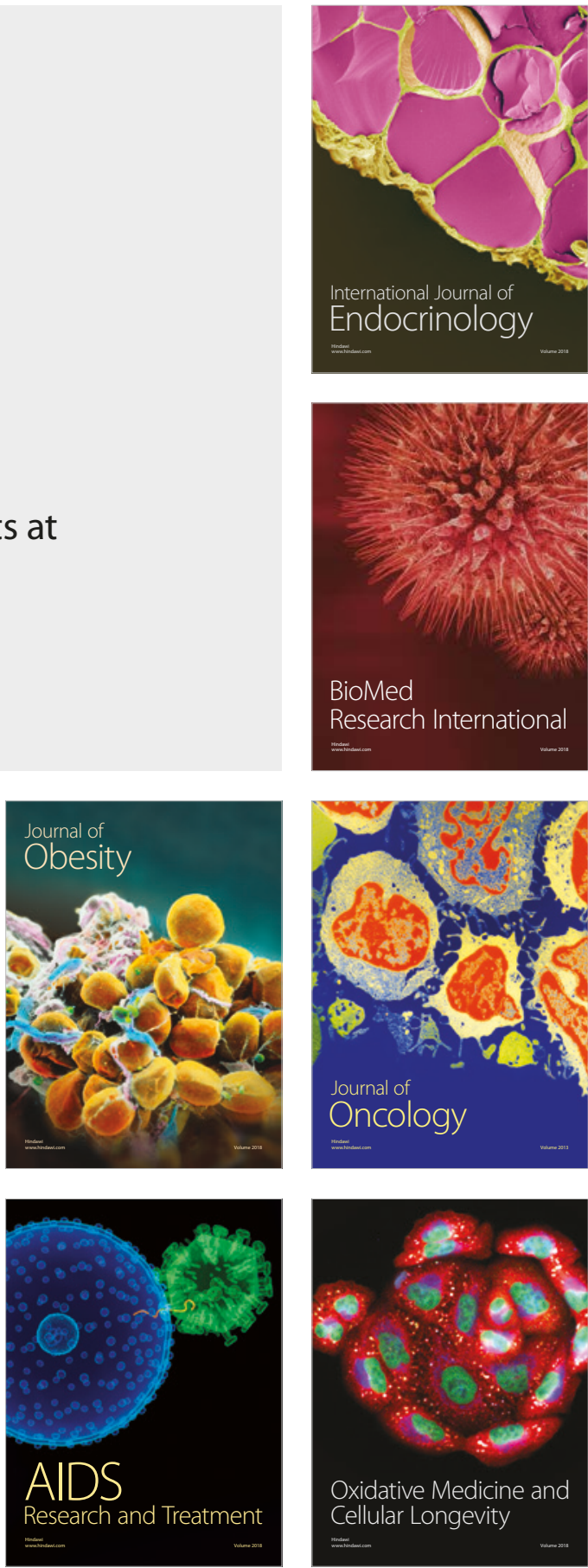